\title{
Creatine Metabolism and Safety Profiles after Six-Week Oral Guanidinoacetic Acid Administration in Healthy Humans
}

\author{
Sergej M. Ostojic ${ }^{1,2,}$, , Barbara Niess ${ }^{3}$, Marko Stojanovic ${ }^{1,2}$, Milos Obrenovic ${ }^{1}$ \\ 1. Center for Health, Exercise and Sport Sciences, Belgrade, Serbia. \\ 2. Faculty of Sport Sciences \& Tourism, Metropolitan University, Novi Sad, Serbia. \\ 3. AlzChem AG, Trostberg, Germany.
}

$\triangle$ Corresponding author: Sergej M. Ostojic, Exercise Physiology Laboratory, Center for Health, Exercise and Sport Sciences, Stari DIF, Deligradska 27, Belgrade 11000, Serbia. Tel: +381112643242, Fax: +381112643242, E-mail: sergej.ostojic@chess.edu.rs.

( ) Ivyspring International Publisher. This is an open-access article distributed under the terms of the Creative Commons License (http://creativecommons.org/ licenses/by-nc-nd/3.0/). Reproduction is permitted for personal, noncommercial use, provided that the article is in whole, unmodified, and properly cited.

Received: 2012.08.29; Accepted: 2012.12.28; Published: 2013.01.03

\begin{abstract}
Objectives; Guanidinoacetic acid (GAA) is a natural precursor of creatine, yet the potential use of GAA as a nutritional additive for restoring creatine availability in humans has been limited by unclear efficacy and safety after exogenous GAA administration. The present study evaluated the effects of orally administered GAA on serum and urinary GAA, creatine and creatinine concentration, and on the occurrence of adverse events in healthy humans. Methods and Results; Twenty-four healthy volunteers were randomized in a double-blind design to receive either GAA (2.4 grams daily) or placebo (PLA) by oral administration for 6 weeks. Clinical trial registration: www.clinicaltrials.gov, identification number NCT0I I 33899. Serum creatine and creatinine increased significantly from before to after administration in GAA-supplemented participants $(P<0.05)$. The proportion of participants who reported minor side effects was $58.3 \%$ in the GAA group and $45.5 \%$ in the placebo group $(P=0.68)$. A few participants experienced serum creatine levels above $70 \mu \mathrm{mol} / \mathrm{L}$. Conclusion; Exogenous GAA is metabolized to creatine, resulting in a significant increase of fasting serum creatine after intervention. GAA had an acceptable side-effects profile with a low incidence of biochemical abnormalities.
\end{abstract}

Key words: Creatine synthesis, Creatinine, Clinical markers.

\section{Introduction}

Guanidinoacetic acid (GAA) occurs naturally in the human body and acts as a precursor of creatine, the latter playing an important role as an energy carrier/mediator in the cell $[1,2]$. GAA itself along with L-ornithine is formed in an enzyme-catalyzed step from L-arginine and glycine, mainly in the kidney and pancreas. This first step in the creatine biosynthesis pathway was found to be rate-limiting as the respective enzyme L-arginine-glycine amidinotransferase (AGAT) is subject to feedback inhibition of creatine on a pretranslational stage [3-5]. The second enzyme in the pathway is GAA N-methyltransferase (GAMT), which catalyzes the transfer of a methyl group from $S$-adenosylmethionine (SAM) to GAA to form creatine and $S$-adenosylhomocysteine (SAH) mainly in the liver. For GAMT no feedback control by creatine was observed [1]. Creatine is then released from the liver into the circulation where it can be taken up, via a specific transporter, by various tissues [6]. Daily turnover of creatine in humans ( $\sim 2$ grams) must be replaced from dietary animal protein or de novo synthesis from GAA [2]. It is well known that exogenous 
creatine can help to replenish cellular levels of creatine in physically actives, ageing population, and neurodegenerative and neuromuscular diseases [7], yet the power and safety of GAA as a nutritional additive for restoring creatine availability is unclear.

The oral application of GAA is not a new concept and several studies evaluated the metabolic and clinical effects of GAA. According to research in rodents [8] short-term oral administration of GAA increases the serum level of creatine to a similar extent like an equimolar dose of creatine, thus showing an impact on creatine metabolism. Stead and co-workers [8], and Fukada and co-workers [9] observed moderate hyperhomocysteinemia after oral administration of GAA in rats, whereas Zugno et al. [10] noticed disturbances in antioxidant system after intrastriatal administration. Recent work in broilers showed beneficial effects of oral GAA administration on growth performance and feed conversion ratio. The transformation of GAA into creatine was evidenced by an increase in serum and muscle creatine levels [11, 12]. Early studies in humans revealed favorable effects of oral administration of GAA in patients with cardiac decompensation, arthritis, anxiety and depression [13-16], yet these studies omitted to examine changes in creatine concentration in serum and urine after GAA administration. Although the latter studies found no side-effects, the authors did report only limited details about the effect of GAA on clinical markers of health status. The main aim of the present study was: a) to investigate whether daily oral administration of GAA had an effect on creatine metabolism; b) to monitor the occurrence of clinical and biochemical adverse events during GAA supplementation.

\section{Methods}

Twenty-four healthy volunteers (age $22.3 \pm 1.5 \mathrm{y}$, weight $69.0 \pm 12.6 \mathrm{~kg}$, height $175.1 \pm 10.5 \mathrm{~cm} ; 12$ men and 12 women) participated in this study. The study was conducted according to the guidelines laid down in the Declaration of Helsinki and all procedures involving human subjects were approved by the local IRB (No. 05/A-2010/014). Written informed consent was obtained from all subjects. Inclusion criteria comprised: age between 20 and 30 years, no preexisting clinical medical conditions, normal renal function (serum creatinine $<110 \mu \mathrm{mol} / \mathrm{L}$ for men and $<90$ $\mathrm{mmol} / \mathrm{l}$ for women), physically active participants (4 hours per week moderate-intensity physical activity) experienced in sport training ( $>2$ years), and no use of any dietary supplement within the 60 days before study commence. A double-blind, placebo-controlled, randomized trial was performed to assess the effect of oral GAA administration (2.4 grams daily) as compared with placebo (inulin) - both administered for 6 weeks in physically active volunteers - on serum and urine creatine, creatinine and GAA, liver and muscle enzymes, and the rate of adverse effects. The treatment formulation was provided by AlzChem AG (Trostberg, Germany) in capsule form, and the participants were instructed to take the intervention $(8$ capsules) in the morning before breakfast. Participants were administered with single dose of GAA per day as more convenient and cost-effective protocol, with better compliance and acceptable safety as compared to multiple-dose application in general [17]. Dosage of GAA administered (2.4 grams per day) was calculated as equimolar equivalent to 3 grams of creatine, a dose known to effectively increased plasma creatine concentration after 6 weeks of administration [18]. Furthermore, the daily turnover of creatine is about 2 - 2.5 grams [19] corresponding to a GAA flux of $1.8-2.3 \mathrm{~g}$ per day, and 2.4 gram is close this daily flux. Inulin in placebo was used as an inert ingredient that has no proven effect on creatine metabolism and is generally recognized as safe by the U.S. Food and Drug Administration [20]. During the intervention, each subject received an individualized meal plan, with diets were prescribed according to the guidelines of ACSM and ADA [21] in aim to ensure similar intake of foods containing animal protein (source of creatine and/or GAA). Individual energy intake was calculated from estimated basal metabolic rate and physical activity level, with prescribed diet supplied $60-65 \%$ energy from carbohydrate, $20-25 \%$ from fat and $12-16 \%$ from protein. Compliance was monitored by analyzing 3-day food records with average daily energy intake and macronutrient content calculated (Nutribaze, Phoenix, AR, USA). Since AGAT is negatively regulated by creatine [4], the amount of creatine brought by the food was calculated according to the food data tables for creatine [22-24]. Three-day records were collected during the study at two-week interval, with no significant treatment $v$ s. time interaction was found for total calories, macronutrient and creatine intake during the study (Table 1).

Volunteers were randomly assigned to receive GAA (12 participants) or placebo (12 participants) and women had an equal probability of assignment to the groups. All subjects were included in the intention-to-treat population. At baseline, after two, four and six weeks subjects provided both fasting blood samples and 24-h urine. Urines were collected in a plastic bottle with an aliquot $(10 \mathrm{ml})$ of the homogenized sample analyzed for GAA, creatine and creatinine. Blood was collected from a radial vein into gel vacutainer for biochemical variables, and $7.5 \%$ 
K3-EDTA vacutainer for homocysteine. Creatine, GAA and creatinine in both serum and urine samples were analyzed by precolumn derivatization HPLC [25]. Plasma homocysteine was measured with a fluorescence polarization immunoassay method. Liver and muscle enzymes were monitored as clinical indicators of skeletal muscle, heart and liver stress during the intervention. Serum activities of aspartate aminotransferase, alanine aminotransferase, alkaline phosphatase, gamma-glutamyl transpeptidase, and creatine kinase were analyzed by an automated analyzer (RX Daytona, Randox Laboratories Ltd., Crumlin, UK). Participants were instructed to report any adverse effects of the supplementation protocol through an open-ended questionnaire for self-assessment of well-being and side-effects (e.g. diarrhoea, nausea, weight gain, muscle cramps) during the study. The primary efficacy outcome was the change in serum creatine level at 6 weeks after administration (effect size of 1.0) in the GAA group over the PLA group. Allowing for $>80 \%$ power, it was estimated that 10 participants per group would be required in the final analyses. This was adjusted to 12 subjects per group to account for a predicted $20 \%$ dropout. The primary safety outcome was the rate of side effects during the treatment period. All results were expressed as mean \pm standard deviation (SD) for continuous variables and rates for categorical variables. For group comparison at a series of time points we firstly identified and calculated area under the curve (AUC) [26] for all dependent variables for each subject. Second, summary measures (mean AUC) for each group were tested with Shapiro-Wilk test for the normality of distribution, and with Bartlett's test for the homogeneity of the variances. When homogenous variances were verified for normally distributed data, summary measures were compared by unpaired two-tailed Student's $t$ test. Welch's $t$ test was used to make the comparison between the two groups when non-homogenous variances were identified. Non-normally distributed mean AUC were compared using the two independent samples Wilcoxon rank sum test. The rates of side-effects occurrence between the GAA and placebo group were compared using the Fisher exact probability test. Significance level was set at 0.05 .

\section{Results}

A total of 23 participants completed the follow-up measures after 6 weeks. One female subject from the placebo group was lost during the intervention period due to reasons not connected to the study per se. The proportion of participants who reported minor side effects was $58.3 \%$ (7 out of 12 ) in the GAA intervention group and $45.5 \%$ (5 out of 11 ) in the placebo group (cumulative incidence difference [CID] = $12.8 \%$; $95 \%$ confidence interval $[\mathrm{CI}]=45.8 \%$ to $24.5 \%$, $P=0.68$ ) (Table 2). The frequency of reported adverse effects was similar between two groups. The rate of abnormal biochemical values was low. A higher incidence of elevated serum creatinine was observed in the GAA group $(88.3 \%$, vs. $9.1 \%$ with placebo; CID = $74.2 \% ; 95 \% \mathrm{CI}=88.4 \%$ to $34.1 \%, P=0.0006)$. The rate of hyperhomocysteinemia was $58.3 \%$ in the GAA group and $18.2 \%$ in the placebo group (CID $=40.1 \%$; $95 \% \mathrm{CI}=66.0 \%$ to $0.6 \%, P=0.09$ ). After six weeks of supplementation all subjects had a plasma homocysteine level below $15 \mu \mathrm{mol} / \mathrm{L}$. Proteinuria was not found in either group. No gender differences were found for rates of self-reported clinical and biochemical adverse events in either intervention group.

Table I. Energy, macronutrient and creatine intake during the study. Values are mean \pm SD.

\begin{tabular}{|c|c|c|c|c|c|c|c|c|c|}
\hline & \multicolumn{4}{|c|}{ Placebo $(n=11)$} & \multicolumn{4}{|c|}{ GAA $(n=12)$} & \multirow[t]{2}{*}{$P$ * } \\
\hline & Baseline & Week 2 & Week 4 & Week 6 & Baseline & Week 2 & Week 4 & Week 6 & \\
\hline $\begin{array}{l}\text { Total energy intake } \\
\text { (kcal/day) }\end{array}$ & $3173 \pm 649$ & $3492 \pm 727$ & $3670 \pm 716$ & $3806 \pm 624$ & $3467 \pm 870$ & $3594 \pm 984$ & $3707 \pm 1030$ & $3827 \pm 886$ & 0.59 \\
\hline Carbohydrates (\%) & $62.1 \pm 4.4$ & $64.8 \pm 5.6$ & $65.5 \pm 3.7$ & $64.9 \pm 4.0$ & $63.9 \pm 5.8$ & $64.2 \pm 5.2$ & $64.4 \pm 4.1$ & $64.9 \pm 4.4$ & 0.98 \\
\hline Lipids (\%) & $23.0 \pm 4.1$ & $21.4 \pm 5.0$ & $20.9 \pm 3.7$ & $20.7 \pm 2.8$ & $23.2 \pm 6.0$ & $21.6 \pm 4.2$ & $21.0 \pm 3.7$ & $21.8 \pm 3.5$ & 0.58 \\
\hline Proteins (\%) & $14.9 \pm 3.7$ & $13.8 \pm 5.0$ & $13.6 \pm 4.7$ & $14.4 \pm 4.4$ & $12.9 \pm 4.3$ & $14.3 \pm 4.5$ & $14.6 \pm 4.9$ & $13.3 \pm 5.0$ & 0.45 \\
\hline Creatine (g/day) & $0.39 \pm 0.08$ & $0.42 \pm 0.09$ & $0.44 \pm 0.09$ & $0.48 \pm 0.08$ & $0.39 \pm 0.10$ & $0.45 \pm 0.12$ & $0.47 \pm 0.13$ & $0.45 \pm 0.10$ & 0.78 \\
\hline
\end{tabular}

Note $^{*} P$ value from two-way ANOVA with repeated measures for treatment $v$ s. time interaction. 
Table 2. Self-reported clinical and biochemical adverse events.

\begin{tabular}{|c|c|c|c|}
\hline Event & $\begin{array}{l}\text { Placebo } \\
(n=11)\end{array}$ & $\begin{array}{l}\text { GAA } \\
(n=12)\end{array}$ & $P *$ \\
\hline \multicolumn{4}{|l|}{ Reported event - no. } \\
\hline Swallowing problems & 5 & 4 & 0.68 \\
\hline Heartburn & 4 & 4 & 1.00 \\
\hline Intestinal cramping & 2 & 3 & 1.00 \\
\hline Diarrhoea & 2 & - & 0.22 \\
\hline Muscle cramping & - & 2 & 0.48 \\
\hline Appetite increase & 1 & 1 & 0.99 \\
\hline Weight gain & 1 & 3 & 0.59 \\
\hline Bloatedness & - & 3 & 0.22 \\
\hline Nausea & - & 2 & 0.48 \\
\hline Abdominal pain & - & 1 & 0.99 \\
\hline \multicolumn{4}{|l|}{ Abnormal biochemical value - no. } \\
\hline Aspartate aminotransferase $>40 \mathrm{IU} / \mathrm{L}$ & - & 1 & 0.99 \\
\hline Alanine aminotransferase $>56 \mathrm{IU} / \mathrm{L}$ & - & - & 0.99 \\
\hline Creatine kinase $>400 \mathrm{IU} / \mathrm{L}$ & 1 & 2 & 0.99 \\
\hline $\begin{array}{l}\text { Gamma-glutamyl transpeptidase > } 51 \\
\text { IU/L }\end{array}$ & - & - & 0.99 \\
\hline Alkaline phosphatase > $140 \mathrm{IU} / \mathrm{L}$ & - & - & 0.99 \\
\hline Hyperhomocysteinemia $†$ & 2 & 7 & 0.09 \\
\hline Elevated serum creatinine $\ddagger$ & 1 & 10 & 0.0006 \\
\hline Proteinuria $\S$ & - & - & 0.99 \\
\hline
\end{tabular}

Note † Hyperhomocysteinemia was defined as total plasma homocysteine $>10.4$ $\mu \mathrm{mol} / \mathrm{L}$ for women and $>11.4 \mu \mathrm{mol} / \mathrm{L}$ for men. $\ddagger$ Elevated serum creatinine was defined as serum creatinine $>90 \mu \mathrm{mol} / \mathrm{L}$ for women and $>110 \mu \mathrm{mol} / \mathrm{L}$ for men. § Proteinuria was defined as $2+$ or greater protein on urinalysis during the follow-up period in participants with a negative finding or trace protein at baseline. ${ }^{*} P$ value from Fisher exact probability test.

The majority of subjectively reported adverse events occurred as single episode (Table 3) at 15 minutes to 2 hours post-treatment at the first day of administration. Two female participants from PLA (2 out of 11), and one female and one male participant from GAA (2 out of 12) reported 2-3 episodes of adverse events during the first two weeks of interven- tion. No additional side effects were reported from week 2 throughout the end of the study.

Changes in serum and urine guanidino compounds, and liver and muscle enzymes during the study are presented in Table 4. GAA intervention significantly increased serum GAA, creatine, creatinine and total homocysteine level $(P<0.05)$, while liver and muscle enzyme profiles and urinary outcomes were not affected by GAA intervention. Serum creatine and creatinine were elevated by $15.3 \mu \mathrm{mol} / \mathrm{L}$ $(95 \% \mathrm{CI}=10.2-20.5 \mu \mathrm{mol} / \mathrm{L})$, and by $19.3 \mu \mathrm{mol} / \mathrm{L}$ (95\% CI $=10.1-28.5 \mu \mathrm{mol} / \mathrm{L})$ after six weeks of administration in the GAA group, respectively. Furthermore, total plasma homocysteine increased for 2.6 $\mu \mathrm{mol} / \mathrm{L}(95 \% \mathrm{CI}=1.3-3.9 \mu \mathrm{mol} / \mathrm{L})$ from before to after administration in GAA-supplemented participants.

Table 3. Frequency of self-reported adverse events during the study.

\begin{tabular}{|c|c|c|c|c|c|c|}
\hline \multirow[t]{2}{*}{ Event } & \multicolumn{3}{|c|}{ Placebo $(n=11)$} & \multicolumn{3}{|c|}{ GAA $(n=12)$} \\
\hline & $\begin{array}{l}\text { Single } \\
\text { episode }\end{array}$ & $\begin{array}{l}\text { Few } \\
\text { times }\end{array}$ & Everyday & $\begin{array}{l}\text { Single } \\
\text { episode }\end{array}$ & $\begin{array}{l}\text { Few } \\
\text { times }\end{array}$ & Everyday \\
\hline $\begin{array}{l}\text { Swallowing } \\
\text { problems }\end{array}$ & 3 & 2 & - & 2 & 2 & - \\
\hline Heartburn & 2 & 2 & - & 3 & 1 & - \\
\hline $\begin{array}{l}\text { Intestinal } \\
\text { cramping }\end{array}$ & 1 & 1 & - & 2 & 1 & - \\
\hline Diarrhoea & 2 & - & - & - & - & - \\
\hline $\begin{array}{l}\text { Muscle } \\
\text { cramping }\end{array}$ & - & - & - & 2 & - & - \\
\hline $\begin{array}{l}\text { Appetite } \\
\text { increase }\end{array}$ & 1 & - & - & - & 1 & - \\
\hline Weight gain & 1 & - & - & 1 & 2 & - \\
\hline Bloatedness & - & - & - & 3 & - & - \\
\hline Nausea & - & - & - & 1 & 1 & - \\
\hline $\begin{array}{l}\text { Abdominal } \\
\text { pain }\end{array}$ & - & - & - & 1 & - & - \\
\hline
\end{tabular}

Table 4. Serum $(S)$ and urinary $(U)$ guanidino coumpounds, and liver and muscle enzymes. Values are mean \pm SD.

\begin{tabular}{|c|c|c|c|c|c|c|c|c|c|c|c|}
\hline & \multicolumn{5}{|c|}{ Placebo $(n=11)$} & \multicolumn{5}{|c|}{$\mathbf{G A A}(n=12)$} & \multirow[t]{2}{*}{$P$} \\
\hline & $\begin{array}{l}\text { Base- } \\
\text { line }\end{array}$ & $\begin{array}{l}\text { Week } \\
2\end{array}$ & $\begin{array}{l}\text { Week } \\
4\end{array}$ & Week 6 & AUC & Baseline & $\begin{array}{l}\text { Week } \\
2\end{array}$ & $\begin{array}{l}\text { Week } \\
4\end{array}$ & Week 6 & AUC & \\
\hline S-GAA $(\mu \mathrm{mol} / \mathrm{L})$ & $\begin{array}{l}2.8 \pm \\
0.2\end{array}$ & $\begin{array}{l}2.8 \pm \\
0.4\end{array}$ & $\begin{array}{l}2.8 \pm \\
0.4\end{array}$ & $2.8 \pm 0.2$ & $\begin{array}{l}16.9 \pm 1.6 \\
\mu \mathrm{mol} \cdot \mathrm{L}^{-1} \cdot \text { week }\end{array}$ & $2.8 \pm 0.3$ & $\begin{array}{l}4.1 \pm \\
3.1\end{array}$ & $\begin{array}{l}4.3 \pm \\
2.5\end{array}$ & $4.3 \pm 1.5$ & $\begin{array}{l}23.8 \pm 11.6 \\
\mu \mathrm{mol} \cdot \mathrm{L}^{-1} \cdot \text { week }\end{array}$ & 0.005 * \\
\hline $\begin{array}{l}\text { S-Creatine } \\
(\mu \mathrm{mol} / \mathrm{L})\end{array}$ & $\begin{array}{l}33.1 \pm \\
5.9\end{array}$ & $\begin{array}{l}34.4 \pm \\
5.3\end{array}$ & $\begin{array}{l}34.0 \pm \\
7.2\end{array}$ & $33.7 \pm 6.6$ & $\begin{array}{l}204.3 \pm 31.2 \\
\mu \mathrm{mol} \cdot \mathrm{L}^{-1} \cdot \text { week }\end{array}$ & $31.5 \pm 10.5$ & $\begin{array}{l}46.1 \pm \\
14.0\end{array}$ & $\begin{array}{l}48.1 \pm \\
18.1\end{array}$ & $46.8 \pm 15.6$ & $\begin{array}{l}266.7 \pm 87.5 \\
\mu \mathrm{mol} \cdot \mathrm{L}^{-1} \cdot \text { week }\end{array}$ & $0.04 \dagger$ \\
\hline $\begin{array}{l}\text { S-Creatinine } \\
(\mu \mathrm{mol} / \mathrm{L})\end{array}$ & $\begin{array}{l}82.7 \pm \\
12.1\end{array}$ & $\begin{array}{l}86.5 \pm \\
11.1\end{array}$ & $\begin{array}{l}85.8 \pm \\
9.9\end{array}$ & $\begin{array}{l}79.9 \pm \\
10.1\end{array}$ & $\begin{array}{l}509.2 \pm 53.3 \\
\mu \mathrm{mol} \cdot \mathrm{L}^{-1} \cdot \text { week }\end{array}$ & $87.6 \pm 10.8$ & $\begin{array}{l}100.5 \pm \\
13.5\end{array}$ & $\begin{array}{l}106.7 \pm \\
14.3\end{array}$ & $106.8 \pm 11.1$ & $\begin{array}{l}608.9 \pm 54.2 \\
\mu \mathrm{mol} \cdot \mathrm{L}^{-1} \cdot \text { week }\end{array}$ & $\begin{array}{l}0.0002 \\
\ddagger\end{array}$ \\
\hline $\begin{array}{l}\text { S-Total homocys- } \\
\text { teine }(\mu \mathrm{mol} / \mathrm{L})\end{array}$ & $\begin{array}{l}8.8 \pm \\
1.9\end{array}$ & $\begin{array}{l}8.8 \pm \\
1.7\end{array}$ & $\begin{array}{l}9.1 \pm \\
2.0\end{array}$ & $8.8 \pm 1.9$ & $\begin{array}{l}53.3 \pm 11.3 \\
\mu \mathrm{mol} \cdot \mathrm{L}^{-1} \cdot \text { week }\end{array}$ & $9.3 \pm 2.0$ & $\begin{array}{l}10.2 \pm \\
2.7\end{array}$ & $\begin{array}{l}11.2 \pm \\
1.8\end{array}$ & $11.9 \pm 1.8$ & $\begin{array}{l}64.1 \pm 11.3 \\
\mu \mathrm{mol} \mathrm{L}^{-1} \cdot \text { week }\end{array}$ & $0.03 \ddagger$ \\
\hline S-AST (IU/L) & $\begin{array}{l}23.4 \pm \\
4.7\end{array}$ & $\begin{array}{l}25.9 \pm \\
4.0\end{array}$ & $\begin{array}{l}25.4 \pm \\
5.0\end{array}$ & $25.2 \pm 4.1$ & $\begin{array}{l}151.8 \pm 22.8 \\
\mathrm{IU} \cdot \mathrm{L}^{-1} \cdot \text { week }\end{array}$ & $25.3 \pm 5.2$ & $\begin{array}{l}25.9 \pm \\
3.9\end{array}$ & $\begin{array}{l}27.6 \pm \\
9.2\end{array}$ & $29.1 \pm 4.5$ & $\begin{array}{l}161.3 \pm 29.3 \\
\text { IU } \text { L }^{-1} \text { week }\end{array}$ & $0.40 \ddagger$ \\
\hline
\end{tabular}




\begin{tabular}{|c|c|c|c|c|c|c|c|c|c|c|c|}
\hline & \multicolumn{5}{|c|}{ Placebo $(n=11)$} & \multicolumn{5}{|c|}{ GAA $(n=12)$} & \multirow[t]{2}{*}{$P$} \\
\hline & $\begin{array}{l}\text { Base- } \\
\text { line }\end{array}$ & $\begin{array}{l}\text { Week } \\
2\end{array}$ & $\begin{array}{l}\text { Week } \\
4\end{array}$ & Week 6 & AUC & Baseline & $\begin{array}{l}\text { Week } \\
2\end{array}$ & $\begin{array}{l}\text { Week } \\
4\end{array}$ & Week 6 & AUC & \\
\hline S-ALT (IU/L) & $\begin{array}{l}24.6 \pm \\
4.9\end{array}$ & $\begin{array}{l}24.0 \pm \\
5.5\end{array}$ & $\begin{array}{l}23.9 \pm \\
5.1\end{array}$ & $24.8 \pm 4.6$ & $\begin{array}{l}145.9 \pm 28.4 \\
\text { IU } \mathrm{L}^{-1} \cdot \text { week }\end{array}$ & $0.4 \pm 3.7$ & $\begin{array}{l}21.0 \pm \\
6.7\end{array}$ & $\begin{array}{l}23.0 \pm \\
7.0\end{array}$ & $22.2 \pm 6.6$ & $\begin{array}{l}130.6 \pm 28.4 \\
\text { IU } \mathrm{L}^{-1} \cdot \text { week }\end{array}$ & $0.21 \ddagger$ \\
\hline S-CK (IU/L) & $\begin{array}{l}162.7 \\
\pm 77.8\end{array}$ & $\begin{array}{l}193.3 \pm \\
90.1\end{array}$ & $\begin{array}{l}177.9 \pm \\
88.2\end{array}$ & $\begin{array}{l}169.7 \pm \\
64.3\end{array}$ & $\begin{array}{l}1079.7 \pm 454.6 \\
\mathrm{IU} \cdot \mathrm{L}^{-1} \text { week }\end{array}$ & $\begin{array}{l}168.3 \pm \\
94.1\end{array}$ & $\begin{array}{l}213.2 \pm \\
100.7\end{array}$ & $\begin{array}{l}275.6 \pm \\
236.5\end{array}$ & $208.0 \pm 135.5$ & $\begin{array}{l}1353.8 \pm 800.1 \\
\mathrm{IU} \cdot \mathrm{L}^{-1} \cdot \text { week }\end{array}$ & $0.33 \ddagger$ \\
\hline $\begin{array}{l}\text { S-Gamma-GT } \\
\text { (IU/L) }\end{array}$ & $\begin{array}{l}16.7 \pm \\
6.2\end{array}$ & $\begin{array}{l}17.0 \pm \\
6.7\end{array}$ & $\begin{array}{l}19.4 \pm \\
8.8\end{array}$ & $16.4 \pm 4.1$ & $\begin{array}{l}105.5 \pm 26.9 \\
\text { IU } \cdot L^{-1} \cdot \text { week }\end{array}$ & $13.1 \pm 4.7$ & $\begin{array}{l}18.4 \pm \\
6.8\end{array}$ & $\begin{array}{l}14.9 \pm \\
5.5\end{array}$ & $16.9 \pm 4.9$ & $\begin{array}{l}96.7 \pm 26.3 \\
\text { IU } \cdot L^{-1} \text { week }\end{array}$ & $0.44 \ddagger$ \\
\hline S-ALP (mmol/L) & $\begin{array}{l}46.6 \pm \\
15.8\end{array}$ & $\begin{array}{l}49.6 \pm \\
15.5\end{array}$ & $\begin{array}{l}46.9 \pm \\
14.3\end{array}$ & $\begin{array}{l}51.9 \pm \\
19.2\end{array}$ & $\begin{array}{l}291.8 \pm 86.3 \\
\text { mmol } \mathrm{L}^{-1} \text { week }\end{array}$ & $46.5 \pm 15.1$ & $\begin{array}{l}55.7 \pm \\
15.6\end{array}$ & $\begin{array}{l}53.4 \pm \\
15.3\end{array}$ & $50.2 \pm 18.8$ & $\begin{array}{l}314.8 \pm 85.1 \\
\mathrm{mmol} \mathrm{L}^{-1} \text { 'week }\end{array}$ & $0.53 \ddagger$ \\
\hline U-GAA $(\mu \mathrm{mol} / \mathrm{L})$ & $\begin{array}{l}158.3 \\
\pm 44.9\end{array}$ & $\begin{array}{l}195.3 \pm \\
51.5\end{array}$ & $\begin{array}{l}190.7 \pm \\
59.0\end{array}$ & $\begin{array}{l}183.4 \pm \\
53.2\end{array}$ & $\begin{array}{l}1111.6 \pm 256.7 \\
\mu \mathrm{mol} \cdot \mathrm{L}^{-1} \cdot \text { week }\end{array}$ & $\begin{array}{l}162.1 \pm \\
43.7\end{array}$ & $\begin{array}{l}231.3 \pm \\
109.9\end{array}$ & $\begin{array}{l}239.8 \pm \\
90.1\end{array}$ & $264.3 \pm 105.2$ & $\begin{array}{l}1368.6 \pm 468.6 \\
\mu \mathrm{mol} \cdot \mathrm{L}^{-1} \cdot \text { week }\end{array}$ & 0.09 * \\
\hline U-Creatine (mg/L) & $\begin{array}{l}22.0 \pm \\
5.3\end{array}$ & $\begin{array}{l}26.3 \pm \\
7.5\end{array}$ & $\begin{array}{l}25.7 \pm \\
11.2\end{array}$ & $\begin{array}{l}27.1 \pm \\
13.0\end{array}$ & $\begin{array}{l}153.6 \pm 45.0 \\
\mathrm{mg} \cdot \mathrm{L}^{-1} \cdot \text { week }\end{array}$ & $21.0 \pm 3.5$ & $\begin{array}{l}32.7 \pm \\
17.7\end{array}$ & $\begin{array}{l}34.8 \pm \\
15.6\end{array}$ & $40.4 \pm 26.3$ & $\begin{array}{l}196.4 \pm 61.6 \\
\mathrm{mg} \cdot \mathrm{L}^{-1} \cdot \text { week }\end{array}$ & $0.07 \ddagger$ \\
\hline U-Creatinine $(\mathrm{g} / \mathrm{L})$ & $\begin{array}{l}1.1 \pm \\
0.4\end{array}$ & $\begin{array}{l}1.2 \pm \\
0.4\end{array}$ & $\begin{array}{l}1.2 \pm \\
0.4\end{array}$ & $1.2 \pm 0.3$ & $\begin{array}{l}7.2 \pm 1.9 \\
\text { g } \mathrm{L}^{-1} \text { week }\end{array}$ & $1.1 \pm 0.4$ & $\begin{array}{l}1.3 \pm \\
0.6\end{array}$ & $\begin{array}{l}1.3 \pm \\
0.4\end{array}$ & $1.8 \pm 0.4$ & $\begin{array}{l}8.0 \pm 2.1 \\
\mathrm{~g} \cdot \mathrm{L}^{-1} \cdot \text { week }\end{array}$ & $0.35 \ddagger$ \\
\hline
\end{tabular}

Note GAA - guanidinoacetic acid; AST - aspartate aminotransferase; ALT - alanine aminotransferase; CK - creatine kinase; Gamma-GT - gamma-glutamyl transpeptidase; ALP - alkaline phosphatase; AUC - area under the curve, is defined as the area under the plot of serum/urine concentration of selected outcome (not logarithm of the concentration) against time after intervention administration. ${ }^{*} P$ value from two independent samples Wilcoxon rank sum test. $\dagger P$ value from two-sample Welch's $t$ test. $\ddagger P$ value from unpaired two-tailed Student's $t$ test.

\section{Discussion}

The present study shows a significant increase in fasting serum creatine in humans who ingest daily supplements of 2.4 grams of GAA for 6 weeks. This implies that GAA is absorbed from the intestinal tract, enters the circulation and is methylated to yield creatine. Although literature contains only limited data on GAA digestibility and availability, a high efficiency of absorption of GAA across gut mucosa is likely [11]. Recent findings confirm this general view for broilers, with Lemme and colleagues [27] found true feacal digestibility of $99.4 \%$ for GAA, suggesting a complete absorption. The roughly 50\% increase of serum creatine levels for the present study is lower than the increase observed by Stead and co-workers [8] who reported that plasma creatine was about 6-fold higher in rats fed with GAA (0.36\% wt/wt GAA) for 2 weeks than in control animals. Such discrepancy is likely to be the result of higher dose of GAA administered for animal study and/or species difference. The intestinal uptake of GAA resulted in both elevated serum GAA and urinary excretion of GAA, leading to the conclusion that the conversion of GAA to creatine is incomplete and that the excess of unmethylated GAA is excreted in urine. The total amount of excreted GAA could not be determined as to missing data for the volume of the $24 \mathrm{~h}$ urine. Daily dose of 2.4 grams GAA seems to be ample since a certain amount of GAA and creatine were excreted in the urine. Since no similar human studies are known to authors, distinct GAA excretion through the kidney after oral administration may indicate either saturated utilization of GAA through GAMT by the liver (or other tissues) and/or limited uptake by various tissues (e.g. kidney, skeletal muscle), but to fully elucidate the distribution, metabolism and excretion of GAA additional studies would be required.

The only known fate of creatine (besides energy-related functions) is its irreversible nonenzymatic conversion to creatinine which is excreted in the urine. Serum creatinine is often used as a marker for kidney function as increased serum level of creatinine may point towards a kidney disorder. On the other hand, serum creatinine is positively correlated with lean body mass thus the serum creatinine level may also reflect the bodily constitution [28, 29]. In the context of creatine supplementation several authors observed an increase of serum creatinine [30-32], whereas others did not find the same effect [33-35]. Considering the correlation between the serum creatinine level and the increased creatine pool after creatine supplementation [36], a rise in serum and urine creatinine levels after intake of GAA as a precursor of creatine seems plausible. In this study, GAA obviously functioned as source of creatine by that augmenting the body own creatine pool leading to an increase in serum and urine creatinine levels. The assessment of the creatine content in skeletal muscle via muscle biopsy could help to further substantiate the indication of an elevated creatine pool after GAA supplementation.

The incidence of most subjective side effects and changes in clinical markers was not different between the two groups, with most side-effects reported as rather single episodes which disappeared during the first week of intervention. The swallowing problems can be clearly attributed to the number and size of 
ingested capsules and could be reduced by the application of a different dosage form. The observation of elevated plasma homocysteine in $58 \%$ of the subjects is a metabolic consequence of exogenous GAA supply. Exogenous GAA enters the biochemical pathway of creatine synthesis and is methylated by S-adenosylmethionine forming creatine and S-adenosylhomocysteine (SAH). SAH formed during this process is subsequently hydrolyzed, thus generating homocysteine, which may then enter either into a new cycle of methyl group transfer or into the transsulfuration pathway, or may be released into the circulation [37, 38]. Previous animal studies reported that feeding a methyl-group acceptor such as GAA directly drives increased homocysteine production which can be corrected by promoting the removal mechanisms $[8,9]$. For future studies, it seems reasonable to either use methyl group donors or serine as additives to suppress the hyperhomocysteinemia induced by medium-term GAA intake $[39,40]$.

Despite the evidence that oral administration of GAA for 6 weeks had an effect on serum and urinary creatine, the present study has several limitations. First, we did not evaluate the possible factors that could affect GAA utilization after exogenous administration. These could include oral GAA bioavailability, pharmacokinetics and biotransformation [11]. Second, the size of the experimental samples could be considered partly limited, in particular considering that both genders were equally considered for group composition. Consequently, although seemingly different, the observed differences between the groups for some outcomes (e.g. urinary GAA and creatine) could not reach the statistically significant level. We partially controlled extraneous factors such as nutrition, yet calculation of GAA consumed from food sources was not conducted for the present study. Moreover, the total amount of urinary GAA, creatine and creatinine excreted for 24 hours was not determined, as well as the excretion of GAA by feces was not evaluated. Thus, the available data did not allow to exactly balancing the difference between the intake of GAA and creatine and the excretion of both compounds. For this study we recruited young physically active volunteers due to rather positive response rates and low incidence of no-shows during experiment [41]. On the other hand, older people probably need more GAA and creatine due to sarcopenia and declined renal function during ageing. Further investigation on GAA should therefore evaluate the effects of GAA administration on safety, creatine metabolism and age-related muscle mass loss in this particular population. During this study we assessed only a few important key components of creatine metabolism neglecting further parameters that are or might be directly or indirectly connected to creatine metabolism. Since arginine and homoarginine are suggested to interact with creatine/energy metabolism [42-44], it might be possible that both are potential confounders for GAA mediated creatine generation through AGAT. Although not measured in the present investigation, it will be interesting for future studies to see whether additional consideration of arginine and homoarginine impact on the effect of exogenous GAA on serum and urine creatine/creatinine levels.

In conclusion, it appears that supplemental GAA is converted to creatine, with a significant increase in fasting serum creatine (up to $50 \%$ after 6 weeks). A few participants experienced a fasting serum creatine levels above $70 \mu \mathrm{mol} / \mathrm{L}$. GAA had an acceptable side-effects profile with a low incidence of biochemical abnormalities.

\section{Acknowledgements}

The authors thank the research participants for their dedication. We thank Dr. Radmila Vrzic and Dr. Nadezda Majkic for their assistance with biochemical data retrieval; Mirjana Stojanovic for statistical support; and the staff of the exercise physiology laboratory, Bojan Medjedovic, Dragoljub Veljovic, Kristina Kanostrevac and Milan Barbir. This study was supported by grant no. AN_85E_S09 from AlzChem AG (Trostberg, Germany). Trial identification: clinicaltrials.gov number NCT01133899.

\section{Competing Interests}

The authors have declared that no competing interest exists. None of the funding sources had any role in the design and conduct of the study. All authors reviewed the paper, and read and approved the final manuscript. Study concept and design: SMO. Acquisition of data: SMO, MS \& MO. Analysis of the data: SMO. Interpretation of data: SMO \& BN. Drafting of the manuscript: SMO \& BN. Critical revision of the manuscript for important intellectual content: SMO \& MO. Statistical analysis: SMO \& MS.

\section{References}

1. Walker JB. Creatine: biosynthesis, regulation, function. Adv Enzymol Relat Areas Mol Biol. 1979; 50: 177-242.

2. Wyss M, Kaddurah-Daouk R. Creatine and creatinine metabolism. Physiol Rev. 2000;80:1107-213.

3. Van Pilsum JF. Evidence for a dual role of creatine in the regulation of kidney transamidinase activities in the rat. J Nutr. 1971;101:1085-92.

4. McGuire DM, Grioss MD, Van Pilsum JF, et al. Repression of rat kidney L-arginine:glycine amidinotransferase synthesis by creatine at a pretranslational level. J Biol Chem. 1984; 259: 12034-8.

5. Edison EE, Brosnan ME, Meyer C, et al. Creatine synthesis: production of guanidinoacetate by the rat and human kidney in vivo. Am J Physiol Renal Physiol. 2007; 293: F1799-804.

6. Snow RJ, Murphy RM. Creatine and the creatine transporter: a review. Mol Cell Biochem. 2001; 224: 169-81. 
7. Brosnan JT, Brosnan ME. Creatine: endogenous metabolite, dietary, and therapeutic supplement. Annu Rev Nutr. 2007; 27: 241-61.

8. Stead LM, Au KP, Jacobs RL, et al. Methylation demand and homocysteine metabolism: effects of dietary provision of creatine and guanidinoacetate. Am J Physiol Endocrinol Metab. 2001; 281: E1095-100.

9. Fukada S, Setoue M, Morita T, et al. Dietary eritadenine suppresses guanidinoacetic acid-induced hyperhomocysteinemia in rats. J Nutr. 2006; 136: 2797-802

10. Zugno AI, Stefanello FM, Scherer EB, et al. Guanidinoacetate decreases antioxidant defenses and total protein sulfhydryl content in striatum of rats. Neurochem Res. 2008; 33: 1804-10.

11. European Food Safety Authority. Safety and efficacy of guanidinoacetic acid as feed additive for chickens for fattening. EFSA J. 2009; 988: 1-30.

12. Michiels J, Maertens L, Buyse J, et al. Supplementation of guanidinoacetic acid to broiler diets: effects on performance, carcass characteristics, meat quality, and energy metabolism. Poult Sci. 2012; 91: 402-12.

13. Borsook ME, Borsook H. Treatment of cardiac decompensation with betaine and glycocyamine. Ann West Med Surg. 1951; 5: 830-55.

14. Graybiel A, Patterson CA. Use of betaine and glycocyamine in the treatment of patients with heart disease: preliminary report. Ann West Med Surg. 1951; 5:.863-75.

15. Higgins AR, Harper HA, Kline EF, et al. Effects of creatine precursors in arthritis; clinical and metabolic study of glycocyamine and betaine. Calif Med. 1952; 77: 14-8.

16. Dixon HH, Dickel HA, Shanklin JG, et al. Therapy in anxiety states and anxiety complicated by depression. West J Surg Obstet Gynecol. 1954; 62: 338-41.

17. Claxton AJ, Cramer J, Pierce C. A systematic review of the associations between dose regimens and medication compliance. Clin Ther. 2001; 23: 1296-310.

18. Rawson ES, Stec MJ, Frederickson SJ, et al. Low-dose creatine supplementation enhances fatigue resistance in the absence of weight gain. Nutrition. 2011; 27: 451-5.

19. Benzi G. Is there a rationale for the use of creatine either as nutritional supplementation or drug administration in humans participating in a sport? Pharmacol Res. 2000; 41: 255-64

20. [Internet] GRAS Notice No.GRN000118. http://www.cfsan.fda.gov/ $\sim \mathrm{rdb}$ /opa-g118.html.

21. American College of Sports Medicine, American Dietetic Association, Dietitians of Canada. Joint Position Statement: nutrition and athletic performance. Med Sci Sports Exerc. 2000; 32: 2130-45.

22. Balsom PD, Söderlund K, Ekblom B. Creatine in humans with special reference to creatine supplementation. Sports Med. 1994; 18: 268-80.

23. del Campo G, Gallego B, Berregi I, Casado JA. Creatinine, creatine and protein in cooked meat products. Food Chem. 1998; 63: 187-90.

24. Pais P, Salmon CP, Knize MG, Felton JS. Formation of mutagenic/carcinogenic heterocyclic amines in dry-heated model systems, meats, and meat drippings. J Agric Food Chem. 1999; 47: 1098-108.

25. Carducci C, Birarelli M, Leuzzi V, et al. Guanidinoacetate and creatine plus creatinine assessment in physiologic fluids: an effective diagnostic tool for the biochemical diagnosis of arginine:glycine amidinotransferase and guanidinoacetate methyltransferase deficiencies. Clin Chem. 2002; 48: $1772-8$.

26. Jaki T, Wolfsegger MJ, Ploner M. Confidence intervals for ratios of AUCs in the case of serial sampling: a comparison of seven methods. Pharm Stat. 2009; 8: 12-24.

27. Lemme A, Tossenberger J, Ringel J. Digestibility and availability of the creatine source guanidinoacetic acid in broilers. Poult Sci. 2007; 86(Suppl 1): 153.

28. Mayhew DL, Mayhew JL, Ware JS. Effects of long-term creatine supplementation on liver and kidney functions in American college football players. Int J Sport Nutr Exerc Metabol. 2002; 12: 453-60.

29. Heymsfield SB, Arteaga C, McManus C, et al. Measurement of muscle mass in humans: validity of the 24-hour urinary creatinine method. Am J Clin Nutr. 1983; 37: 478-94.

30. Hultman E, Söderlund K, Timmons JA, et al. Muscle creatine loading in men. J Appl Physiol. 1996; 81: 232-7.

31. Volek JS, Duncan ND, Mazzetti SA, et al. No effect of heavy resistance training and creatine supplementation on blood lipids. Int J Sport Nutr Exerc Metabol. 2000; 10: 144-56.

32. Deldicque L, Décombaz J, Zbinden Foncea H, et al. Kinetics of creatine ingested as a food ingredient. Eur J Appl Physiol. 2008; 102: 133-43.

33. Poortmans JR, Francaux M. Long-therm oral creatine supplementation does not impair renal function in healthy athletes. Med Sci Sports Exerc. 1999; 31: 1108-10

34. Mihic S, MacDonald JR, McKenzie S, et al. Acute creatine loading increases fat-free mass, but does not affect blood pressure, plasma creati- nine, or CK activity in men and women. Med Sci Sports Exerc. 2000; 32: 291-6.

35. Pline KA, Smith CL. The effect of creatine intake on renal function. Ann Pharmacother. 2005; 39: 1093-6.

36. Gualano B, Ugrinowitsch C, Novaes RB, et al. Effects of creatine supplementation on renal function: a randomized, double-blind, placebo-controlled clinical trial. Eur J Appl Physiol. 2008; 103: 33-40.

37. Selhub J. Homocysteine metabolism. Annu Rev Nutr. 1999; 19: 217-46.

38. Fowler B. Homocysteine: overview of biochemistry, molecular biology, and role in disease process. Seminars Vasc Med. 2005; 5: 77-86.

39. Ohuchi S, Matsumoto Y, Morita T, et al. High-casein diet suppresses guanidinoacetic acid-induced hyperhomocysteinemia and potentiates the hypohomocysteinemic effect of serine in rats. Biosci Biotechnol Biochem. 2008; 72: 3258-64.

40. Setoue M, Ohuchi S, Morita T, et al. Hyperhomocysteinemia induced by guanidinoacetic acid is effectively suppressed by choline and betaine in rats. Biosci Biotechnol Biochem. 2008; 72: 1696-1703.

41. Gul RB, Ali PA. Clinical trials: the challenge of recruitment and retention of participants. J Clin Nurs. 2010; 19: 227-33.

42. Pilz S, Meinitzer A, Tomaschitz A, et al. Low homoarginine concentration is a novel risk factor for heart disease. Heart. 2011; 97: 1222-7.

43. Meinitzer A, Drechsler C, Tomaschitz A, et al. Homoarginine: a new cardiovascular risk marker in hemodialysis patients. J Lab Med. 2011; 35: 153-9.

44. Derave W, Marescau B, Vanden Eede E, Eijnde BO, De Deyn PP, Hespel P. Plasma guanidino compounds are altered by oral creatine supplementation in healthy humans. J Appl Physiol 2004; 97: 852-857. 